Aleksandra Sikorska-Lewandowska

Uniwersytet Mikołaja Kopernika, Toruń

asl@umk.pl

ORCID: https://orcid.org/0000-0002-3234-2502

\title{
Dopuszczalność ingerencji przez sąd w treść uchwały wspólnoty mieszkaniowej - glosa do wyroku Sądu Najwyższego $z$ dnia 21 marca 2019 r., sygn. II CSK 62/18 (krytyczna)
}

http://dx.doi.org/10.12775/SIT.2020.037

Zagadnienie dopuszczalności uchylenia uchwały w części rzadko jest przedmiotem rozważań doktryny, podczas gdy w praktyce zdarzają się orzeczenia sądów, w których dochodzi do uchylenia uchwały w części ${ }^{1}$. Wydaje się, że w sytuacji zaskarżenia uchwały właścicieli lokali sąd jest władny do dowolnego rozstrzygnięcia, a więc zarówno do uchylenia uchwały w całości, jak również w części. Tymczasem nie jest to wcale oczywiste, ponieważ takie uprawnienie nie wynika wprost $\mathrm{z}$ przepisów Ustawy $\mathrm{z}$ dnia 24 czerwca 1994 r. o własności lokali² .

${ }^{1}$ Wyrok Sądu Apelacyjnego w Gdańsku z dnia 28 czerwca 2018 r., V ACa 550/17, niepubl.

${ }^{2}$ Ustawa z dnia 24 czerwca 1994 r. o własności lokali, tekst jednolity: Dz.U. z 2020 r. poz. 1910, dalej: u.w.1. 


\section{Stan faktyczny}

Przedmiotem powództwa w sprawie, w której zapadł glosowany wyrok, było żądanie ustalenia nieistnienia lub żądanie uchylenia uchwały w sprawie wykonania ogrodzenia wokół nieruchomości. Powodem był członek wspólnoty - właściciel lokalu użytkowego, który sprzeciwiał się ogrodzeniu terenu należącego do wspólnoty mieszkaniowej. Co istotne - właściciel tego lokalu nie kwestionował wybudowania ogrodzenia wokół całej nieruchomości, a jedynie nie zgadzał się na część ogrodzenia od strony swojego lokalu użytkowego, ze względu na to, że postrzegał je jako barierę psychologiczną dla klientów. Sąd pierwszej instancji powództwo uwzględnił, a sąd apelacyjny oddalił je. W konsekwencji złożonej skargi kasacyjnej sprawa została poddana rozstrzygnięciu Sądu Najwyższego, ten zaś uchylił wyrok i przekazał sprawę do ponownego rozpoznania.

\section{Rozstrzygnięcie SN - wywody dotyczące uchylenia uchwały w części}

W uzasadnieniu wyroku SN znalazły się m.in. wywody dotyczące możliwości częściowego uchylenia uchwały wspólnoty mieszkaniowej, którym należy poświęcić więcej uwagi. Sąd Najwyższy zauważył, że sąd apelacyjny w ogóle nie rozważał „pośredniego rozwiązania zaistniałego sporu”, które miałoby polegać na uchyleniu uchwały w takiej części, aby doszło do „wyłączenia z ogrodzenia lokalu powódki”. Następnie SN przypomniał, że uchwała właścicieli lokali jest wielostronną czynnością prawną i podał w wątpliwość możliwość przełożenia fizycznej podzielności przedmiotu uchwały na podzielność uchwały jako czynności prawnej. Sąd Najwyższy powołał się na art. $58 \S 3$ kodeksu cywilnego ${ }^{3}$, który dotyczy nieważności części czynności prawnej, oraz stwierdził, że przepis ten nie ma w tej sprawie wprost zastosowania.

${ }^{3}$ Ustawa z dnia 23 kwietnia 1964 r. - Kodeks cywilny, tekst jednolity: Dz.U. 2020 r. poz.174, dalej jako: k.c. 
W dalszej jednak części uzasadnienia wyroku SN jednoznacznie stwierdził, że sąd w procesie o uchylenie uchwały wspólnoty mieszkaniowej nie może orzeczeniem kształtować jej treści. Stanowisko to wymaga szerszego komentarza.

\section{Częśsiowe uchylenie uchwały - poglądy doktryny oraz stanowisko judykatury}

Problem dopuszczalności częściowego uchylenia uchwały dotyczy nie tylko uchwał właścicieli lokali, ale stanowi też przedmiot rozważań w doktrynie prawa handlowego oraz prawa spółdzielczego. Zasadniczo można stwierdzić, że występuje zdecydowana polaryzacja poglądów; prezentowane jest stanowisko, zgodnie $z$ którym uchylenie uchwały w części nie jest dopuszczalne ${ }^{4}$, oraz ujęcie przeciwne, akceptujące taką możliwość ${ }^{5}$. W judykaturze w odniesieniu do uchwał zgromadzeń wspólników w spółkach $z$ o.o. oraz uchwał walnych zgromadzeń spółek akcyjnych dominuje pogląd dopuszczający uchylenie uchwały w części ${ }^{6}$. Stanowisko takie zostało wyrażone także w orzeczeniu Sądu Najwyższego w odniesieniu do uchwały walnego zgromadzenia członków spółdzielni w przedmiocie zmian w statucie tej spółdzielni ${ }^{7}$.

Przeciwnicy dopuszczalności uchylenia uchwały w części podnoszą argumenty związane ze specyfiką uchwały, w szczególności wskazując, że ewentualne zastosowanie art. 58 § 3 k.c. jest wy-

${ }^{4}$ J.P. Naworski, Uchylenie uchwały walnego zgromadzenia spótdzielni, „Przegląd Prawa Handlowego” 2003, nr 2, s. 51; M. Gutowski, Dopuszczalność stosowania art. 58 \$ 3 k.c. do podlegajacych uchyleniu uchwał zgromadzenia wspólników lub walnego zgromadzenia spótek kapitałowych, „Przegląd Prawa Handlowego" 2009, nr 12, s. 19.

${ }^{5}$ K. Bilewska, M. Warzecha, Dopuszczalność stosowania art. 58 § 3 k.c. do uchwał zgromadzeń spółek kapitałowych - polemika, „Przegląd Prawa Handlowego" 2010, nr 7, s. 54

${ }^{6}$ Wyrok SN z dnia 13 maja 2004, V CK 452/04, OSNC 2005, nr 5, poz. 89; wyrok SN z dnia 19 grudnia 2007 r., V CSK 350/07, Lex nr 371391.

7 Wyrok SN z dnia 15 kwietnia 1999 r., I CKN 1088/97, OSNC 1989, nr 11, poz. 193. 
kluczone $z$ tego względu, że w zasadzie niemożliwe jest określenie, jaki byłby wynik głosowania, gdyby uchwała nie zawierała zakwestionowanych postanowień ${ }^{8}$. W odniesieniu do dopuszczalności częściowego uchylenia uchwały spółdzielni wskazano, że literalna wykładnia przepisów prawa spółdzielczego nie daje podstawy do zastosowania argumentum a maiori ad minus, nie można więc twierdzić, że skoro można uchylić uchwałę w całości, to tym bardziej można to zrobić w części, skoro żaden $z$ przepisów nie przewiduje takiego rozwiązania 9 .

Zwolennicy uznania, że art. 58 § 3 k.c. może stanowić podstawę do uchylenia uchwały zgromadzenia wspólników w części, wskazują, że jest to dopuszczalne zarówno w sytuacji uchylenia uchwały, jak i stwierdzenia jej nieważności dzięki zastosowaniu analogii. W związku z odrębną regulacją kodeksu spółek handlowych $^{10}$ przewidującą dwa osobne powództwa służące wyeliminowaniu wadliwej uchwały $\mathrm{z}$ obrotu prawnego, zastosowanie art. 58 $\S 1$ k.c. do wadliwych uchwał zgromadzenia zostało wyłączone, ale zarazem przepisy k.s.h. nie normują zagadnienia dopuszczalności uchylenia uchwały w części, a więc występuje luka regulacyjna. Występowanie luki oraz podobieństwa hipotezy norm uzasadnia zastosowanie analogii ${ }^{11}$. W odniesieniu do argumentu o niemożliwości wykorzystania kryterium subiektywnego, zgodnie z którym w świetle art. 58 § 3 k.c. należy ustalić, czy bez postanowień dotkniętych wadliwością czynność zostałaby dokonana, wskazano, że w przypadku uchwał ocena dokonywana przez sąd powinna być zobiektywizowana - sąd powinien określić, czy dana uchwała może funkcjonować w obrocie prawnym w kształcie nadanym jej po częściowym wyeliminowaniu niektórych postanowień ${ }^{12}$. Wskazuje się, że skoro konstrukcje prawa spółek oparte są na podstawowych konstrukcjach prawa cywilnego, przesądza to o dopuszczalności

8 M. Gutowski, op.cit., s. 24.

9 J.P. Naworski, op.cit., s. 53.

${ }^{10}$ Ustawa $z$ dnia 15 września 2000 r. - Kodeks spółek handlowych, tekst jednolity: Dz.U. 2020 r. poz. 1526; dalej jako: k.s.h.

${ }^{11}$ K. Bilewska, M. Warzecha, op.cit., s. 56.

12 Ibidem. 
uchylenia uchwały w części lub stwierdzenia nieważności części postanowień uchwały ${ }^{13}$.

\section{Stanowisko sądów w odniesieniu do uchwał wspólnot mieszkaniowych}

Wypowiedzi judykatury odnoszące się bezpośrednio do zagadnienia dopuszczalności uchylenia uchwały właścicieli lokali w części nie są liczne i zdają się wyraźnie inspirowane dorobkiem orzecznictwa wypracowanym w odniesieniu do uchwał zgromadzeń spółek kapitałowych oraz uchwał walnych zgromadzeń członków spółdzielni. W orzecznictwie dotyczącym uchwał właścicieli lokali szczególnie wyraźny jest trend nawiązywania do poglądu wyrażonego przez Sąd Najwyższy w wyroku z dnia 13 maja 2004 r., V CK 452/04. W orzeczeniu tym uznano, że art. 58 § 3 k.c. stosuje się również odpowiednio do wzruszalnych uchwał zgromadzeń wspólników, pod warunkiem że zaskarżona część uchwały ma charakter autonomiczny i nie jest nierozerwalnie związana $z$ innymi elementami kwestionowanej czynności prawnej. W razie gdy zaskarżona część czynności prawnej stanowi jej istotny składnik i $z$ okoliczności wynika, że strony nie powzięłyby uchwał bez zakwestionowanych postanowień, stosowanie tego przepisu byłoby niedopuszczalne.

W odniesieniu do uchwał podjętych przez właścicieli lokali w orzecznictwie wyrażono stanowisko, że zakres zaskarżenia może być ograniczony jedynie do części uchwały lub poszczególnych jej postanowień ${ }^{14}$ oraz że uchylenie części uchwały jest możliwe wówczas, gdy kwestionowany fragment ma charakter autonomiczny i nie jest powiązany treściowo $z$ pozostałymi postanowieniami uchwały $^{15}$. Jednocześnie podkreśla się, że niedopuszczalne byłoby

${ }^{13}$ W. Popiołek, w: Kodeks spółek handlowych. Komentarz, red. A. Strzępka, wyd. 7, Warszawa 2015, s. 1076.

14 Wyrok SA w Gdańsku z dnia 23 września 2014 r., V ACa 463/14, Lex nr 1602890.

15 Wyrok SA w Krakowie $z$ dnia 27 listopada 2015 r., I ACa 1131/15, Lex nr 2000494. 
uchylenie fragmentu lub fragmentów określonych postanowień (zapisów) uchwały, ponieważ prowadziłoby to do nieprzewidzianego prawem kształtowania treści tej czynności prawnej. Zdaniem SA $\mathrm{w}$ Warszawie ${ }^{16}$ nie ma podstaw do zanegowania uprawnienia sądu, działającego w ramach art. 25 ust. 1 u.w.l. do odrębnej oceny samodzielnych, pozostających w luźnym związku postanowień tego aktu, mogących być $\mathrm{w}$ istocie przedmiotem odrębnych uchwał. Decydujące znaczenie ma na tej płaszczyźnie to, czy poszczególne elementy zaskarżonej uchwały mają samodzielny charakter, czy też pozostają ze sobą w ścisłym związku i stanowią razem jedną, nierozerwalną całość.

Zdecydowany sprzeciw wobec dopuszczalności częściowego uchylenia uchwały wyraził SA w Łodzi ${ }^{17}$, wskazując, że sąd w ramach kontroli przewidzianej w art. 23-25 u.w.1. nie jest do tego uprawniony, gdyż takie działanie mogłoby zostać poczytane za próbę zobowiązywania wspólnoty mieszkaniowej przez sąd do podjęcia uchwały o określonej treści, czemu w sposób wyraźny sprzeciwia się nie tylko autonomia właścicieli w zakresie zarządu nieruchomością wspólną, lecz również przepisy u.w.l. Refleksja dotycząca ewentualności uchylenia wybranych postanowień uchwały wprowadzającej regulamin porządku domowego została zawarta także w uzasadnieniu wyroku SA w Poznaniu ${ }^{18}$. Sąd ten podkreślił, że nie ma podstaw do jedynie częściowego uchylenia zaskarżonej uchwały, skoro nie można przesądzić, czy bez tych zapisów uchwała w takim kształcie zostałaby w ogóle podjęta. Mogłoby zatem dojść do zdeformowania rzeczywistej woli członków wspólnoty mieszkaniowej, która powinna mieć prawo do kompleksowego, pełnego uregulowania (z tym że w granicach ustawy) wewnętrznych przepisów porządku domowego. Wydaje się, że podkreślając autonomię woli właścicieli lokali w zakresie ustalania treści uchwały, SA opowiedział się w ten

${ }^{16}$ Wyrok SA w Warszawie $z$ dnia 20 listopada 2015 r., VI ACa 1696.14, Lex nr 1968134; wyrok SA w Warszawie z dnia 9 marca 2017 r., VI ACa 2020/15, Lex nr 2295329.

17 Wyrok SA w Łodzi z dnia 31 marca 2015 r., I ACa 1469/14, Lex nr 1675891.

18 Wyrok SA w Poznaniu z dnia 20 maja 2008 r., I ACa 367/08, Lex nr 446185. 
sposób przeciwko częściowemu uchylaniu uchwały, podając zarazem argument o braku możliwości przesądzenia, czy uchwała w innym kształcie zostałaby podjęta.

\section{Dopuszczalność \\ zastosowania art. $58 \S 3$ k.c. do wadliwych uchwał właścicieli lokali}

Zgodnie $\mathrm{z}$ art. 1 § 2 u.w.l. w zakresie nieuregulowanym u.w.l. do własności lokali stosuje się przepisy Kodeksu cywilnego. Odesłanie to, jako wyraz zasady jedności prawa cywilnego ${ }^{19}$, której obowiązywanie przyjmuje się w doktrynie od czasu uchwalenia Kodeksu cywilnego, potwierdza uniwersalność stosowania k.c. także w obszarze regulacji dotyczącej własności lokali. Dla przyjęcia takiego rozwiązania konieczne jest więc przesądzenie, że dana sprawa należy do zakresu nieuregulowanego w u.w.1., wówczas bowiem wprost należy stosować k.c.

Przepis art. 25 ust. 1 u.w.1. przewiduje sankcję wzruszenia uchwały dla określonych w tym przepisie postaci jej wadliwości, tj. przesłanek uchylenia uchwały. W doktrynie przyjęto, że pewne typy wadliwości uchwał leżą poza zakresem tej regulacji, co uzasadnia stosowanie przepisów Kodeksu cywilnego wprost lub odpowiednio do wadliwych uchwał właścicieli lokali ${ }^{20}$. Uznanie, że uchwała właścicieli lokali może być dotknięta sankcją nieważności bezwzględnej, wywołuje pytanie o dopuszczalność zastosowania do niej przepisu art. 58 § 3 k.c., a więc normy, zgodnie $z$ którą, jeżeli nieważnością jest dotknięta tylko część czynności prawnej, czynność pozostaje w mocy co do pozostałych części, chyba że z okoliczności

19 A. Kidyba, Prawo handlowe, wyd. 21, Warszawa 2019, s. 3.

${ }^{20}$ R. Dziczek, Własność lokali. Komentarz. Wzory pozwów i wniosków sądowych, Warszawa 2012, s. 225; A. Sikorska-Lewandowska, Nieważność uchwat właścicieli lokali, „Państwo i Prawo” 2015, nr 2, s. 77; J. Zębala, w: Prawo spółdzielcze i mieszkaniowe. Komentarz, red. K. Osajda, t. VI B, Warszawa 2018 , s. 423. 
wynika, iż bez postanowień dotkniętych nieważnością czynność nie zostałaby dokonana.

Również w przypadku prezentowania poglądu, zgodnie $z$ którym regulacja art. 25 u.w.l., ustanawiająca sankcję wzruszalności uchwał właścicieli lokali także w przypadku ich sprzeczności z prawem, wyłącza zastosowanie art. 58 § 1 k.c., nie można wykluczyć dopuszczalności zastosowania § 3 art. 58 k.c. w drodze analogii. Uchwały właścicieli lokali są bowiem czynnościami prawnymi, a u.w.l. nie reguluje kwestii częściowego ich uchylenia. Wystąpienie luki oraz istnienie podobieństwa stanu faktycznego stanowi podstawę $\mathrm{w}$ prawie cywilnym dla zastosowania analogii.

Regulacja art. $58 \S 3$ k.s.h. zawiera dwie zasadnicze przesłanki stosowania: pierwszą z nich jest nieważność tylko części czynności prawnej, drugą zaś są okoliczności przesądzające o tym, czy czynność w pozostałej części pozostaje w mocy, czy też nie. W doktrynie wskazano, że celem art. 58 § 3 k.c. jest utrzymanie czynności prawnej w zakresie najbliższym temu, czego strony chciały w zakresie dopuszczanym przez prawo; co oznacza, że na gruncie prawa polskiego jest możliwa „redukcja utrzymująca skuteczność"21. Teoria ta zakłada, że jeżeli klauzula umowna obejmuje swym zakresem postanowienia sprzeczne $z$ porządkiem prawnym, to nie należy pozbawiać jej mocy w całości, lecz zredukować do poziomu dopuszczalnego, ale w jak największym stopniu uwzględniającego intencje stron ${ }^{22}$.

Zarówno od strony merytorycznej, jak i procesowej zastosowanie tej regulacji jest niezmierne trudne. Kryterium wskazane w art. 58 § 3 k.c. może znaleźć zastosowanie tylko wtedy, gdy bez części dotkniętej nieważnością umowa nadal zawiera postanowienia konieczne dla tego typu umowy, co odpowiada przesłance „minimalnej treści” uwzględniającej zamierzony typ umowy ${ }^{23}$. Skutek w postaci bezwzględnej nieważności następuje ex lege, a więc sąd

${ }^{21}$ F. Zoll, Kilka uwag na temat tzw. redukcji utrzymujaccej skuteczność, „Transformacje Prawa Prywatnego” 2000, nr 1-2, s. 13.

22 Ibidem, s. 12.

23 R. Trzaskowski, Skutki sprzeczności umów obligacyjnych z prawem, Warszawa 2013, s. 318. 
jedynie stwierdza jego wystąpienie, podczas gdy ustalenia wymaga zaistnienie drugiej przesłanki, a więc okoliczności, które $z$ założenia mają charakter subiektywny, gdyż leżą na płaszczyźnie woli stron. Efektem zastosowania tej regulacji jest ingerencja w treść stosunku cywilnoprawnego, dokonywana przez sąd, stwierdzenie bowiem nieważności części postanowień umowy w istocie prowadzi do modyfikacji jej treści. Strony mogą nie zdawać sobie sprawy z wadliwości dokonanej czynności prawnej, a to rozwiązanie, pozwalające na stwierdzenie nieważności jedynie niektórych elementów czynności prawnej, skutkuje utrzymaniem w mocy umowy, a więc może być korzystnym rozwiązaniem dla stron.

Przeniesienie tych rozważań na płaszczyznę uchwał, jako wielostronnych czynności prawnych, nie jest jednak proste, ze względu na ich specyfikę. Uchwały organów korporacyjnych osób prawnych, takich jak spółki kapitałowe czy spółdzielnie, a także uchwały właścicieli lokali, podejmowane są większością głosów. Zastosowanie znajduje więc tu zasada majoryzacji, której działanie przejawia się w pominięciu głosów osób przeciwnych podjęciu uchwały w sytuacji, gdy większość uprawnionych głosuje za jej przyjęciem. Uchwała, jako suma oświadczeń woli uprawnionych członków organu, stanowi wielostronną czynność prawną, a dochodzi do skutku na podstawie konsensusu większości, lecz nie wszystkich stron tej czynności. Kodeks cywilny nie zawiera regulacji ogólnej dotyczącej specyficznego typu czynności prawnych, jakim są uchwały, a odnosi się głównie do dwustronnych czynności prawnych, a więc umów. Stosowanie regulacji dedykowanych dwustronnym czynnościom prawnym do czynności wielostronnych nastręcza wiele trudności. Dlatego też ustawy szczególne, takie jak k.s.h. czy prawo spółdzielcze, ale również u.w.l., zawierają co do zasady odrębną regulację sankcji wadliwości uchwał kolegialnych organów korporacyjnych osób prawnych (oraz osób ustawowych), gdyż potrzebne były inne niż w przypadku sankcji nieważności przesłanki kontroli merytorycznej treści tych uchwał.

Obowiązywanie zasady jedności prawa cywilnego powoduje jednak, że każdorazowo w razie braku określonej regulacji w ustawie szczególnej zasadne jest korzystanie z przepisów k.c. Dlatego wydaje się, że - co do zasady - teoretycznie można by dopuścić możli- 
wość uchylenia uchwały właścicieli lokali w części, a więc w sytuacji, gdy wadliwość dotyczy jedynie wyraźnie wydzielonych postanowień (wyodrębnionych części) uchwały. Należy jednak zastrzec, że uchylenie części uchwały może nastąpić w sytuacjach zdecydowanie wyjątkowych, a więc takich, gdy w jednej uchwale połączono dwie sprawy, które mogły być przedmiotem dwóch odrębnych uchwał; bądź gdy konstrukcja uchwały pozwala na takie rozwiązanie, gdyż zostanie zachowany jej sens oraz cel jej powzięcia. Takie sytuacje będą miały charakter sporadyczny, za regułę natomiast należy przyjąć, że w przypadku uchwał podejmowanych w celu wyrażenia zgody na dokonanie przez zarząd określonej czynności prawnej takie częściowe uchylenie uchwały raczej nie będzie możliwe. Uchwała nie zawiera zazwyczaj tak licznych postanowień jak umowa, jej konstrukcja bywa prosta, kilkuzdaniowa. Jeśli jej przedmiotem jest wyrażenie zgody na dokonanie przez zarząd wspólnoty mieszkaniowej określonej czynności przekraczającej zakres zwykłego zarządu, to taką uchwałę można jedynie uchylić w całości. Zgoda wyrażona przez właścicieli lokali dotyczy bowiem tej skonkretyzowanej czynności prawnej.

Trudno przyjąć, aby sąd prowadził postępowanie dowodowe w celu ustalenia, jaka treść uchwały byłaby akceptowalna dla właścicieli lokali wobec nieważności części jej postanowień. Wspólnoty mieszkaniowe liczą niekiedy bardzo wielu członków, wydaje się, że przesłuchiwanie tych osób na okoliczność, czy uchwała zostałaby podjęta bez zakwestionowanych postanowień, znacznie przedłużyłoby postępowanie $\mathrm{w}$ sprawie uchylenia uchwały, a więc stan niepewności co do ważności uchwały, podczas gdy ścieranie się poglądów i klarowanie się wspólnego stanowiska powinny odbywać się podczas zebrań i głosowania właścicieli lokali, a nie w sądzie. W tym zakresie należy zgodzić się ze stwierdzeniem, że ustalenie wyniku głosowania, gdyby uchwała nie zawierała zakwestionowanych przez powoda postanowień, jest w zasadzie niemożliwe ${ }^{24}$.

Należy uznać, że nawet przyjęcie obiektywnej oceny przez sąd, czy uchwała nadaje się do wykonania bez wyeliminowanych posta-

${ }^{24}$ M. Gutowski, op.cit., s. 24. 
nowień, i tak skutkuje modyfikacją treści, być może wbrew woli większości właścicieli. To zaś przemawia przeciwko dopuszczalności uchylenia uchwały w części.

\section{Dopuszczalność kształtowania orzeczeniem sądu treści uchwały właścicieli lokali}

W uzasadnieniu glosowanego wyroku znalazło się zdanie o braku możliwości kształtowania przez sąd treści uchwały, tuż po tym, jak SN uznał uchylenie części uchwały za dopuszczalne. Stwierdzenie to wywołuje pytanie o to, czy orzeczenie sądu uchylające część uchwały, a więc część oświadczenia woli właścicieli lokali, nie stanowi właśnie ingerencji w treść uchwały. Prima facie odpowiedź na to pytanie jest pozytywna, każde orzeczenie uchylające uchwałę w części oraz stwierdzające jej nieważność w części stanowi ingerencję $\mathrm{w}$ treść tej uchwały. $\mathrm{W}$ przypadku sankcji wzruszalności, a $z$ tą mamy do czynienia w art. 25 u.w.1., konieczne jest wydanie orzeczenia uchylającego uchwałę, ta sankcja nie występuje ex lege, jak w przypadku sankcji bezwzględnej nieważności określonej w art. $58 \S 1$ k.c.

W uzasadnieniu omawianego orzeczenia Sąd Najwyższy wspomniał o „technicznej i fizycznej podzielności przedmiotu uchwały” (czyli ogrodzenia), co „nie ma przełożenia na podzielność uchwały jako czynności prawnej w tym sensie, że częściowe ogrodzenie nieruchomości $z$ wyłączeniem lokalu powódki może jednak nie realizować zakładanego skarżoną uchwałą i uzasadnionego interesu wspólnoty". To stwierdzenie sądu zasługuje na szerszy komentarz, gdyż przedmiot uchwały nie ma nic do rzeczy w kontekście dopuszczalności uchylenia jej w części. Sąd nie może wydać orzeczenia, w którym dokona modyfikacji treści uchwały w taki sposób, że uchyli ją w zakresie np. wybudowania płotu od strony wschodniej albo części wynagrodzenia za usługę. Sąd nie może uchylić postanowienia uchwały stanowiącego o zaciągnięciu kredytu bankowego na remont budynku, a pozostawić samo postanowienie o wykona- 
niu remontu budynku - skoro remont miał zostać sfinansowany z kredytu. Takie orzeczenie stanowiłoby wprost niedopuszczalną ingerencję w treść uchwały. Tylko wspólnota mieszkaniowa może zmodyfikować treść swego oświadczenia woli - podejmując kolejną uchwałę o innej treści. Do takiego działania może właścicieli lokali zmotywować orzeczenie sądu uchylające podjętą uchwałę w całości. Temu powinno służyć uzasadnienie wyroku uchylającego uchwałę, podkreślające te aspekty, które zostały uznane w danych okolicznościach za naruszające kryteria prawidłowości uchwały.

Trudno zaakceptować sugestię, zawartą w uzasadnieniu wyroku Sądu Najwyższego, o konieczności rozważenia przez sąd drugiej instancji „pośredniego rozwiązania zaistniałego sporu” poprzez ewentualne uchylenie uchwały w części. Kategorycznie należy stwierdzić, że sąd $z$ urzędu nie może ingerować w treść uchwały oraz orzekać wbrew żądaniu powództwa, uwzględniając je w takim przypadku jedynie częściowo, wybiórczo. W przypadku uchwał właścicieli lokali takie orzeczenie nie jest w ogóle możliwe, gdyż wprost stanowiłoby to modyfikację treści uchwały, a do tego było niezgodne z żądaniem pozwu.

Uchylenie uchwały w części, na podstawie art. 58 § 3 k.c. stosowanego per analogiam, może nastąpić tylko w przypadku takiego żądania sformułowanego w powództwie oraz wyłącznie w sytuacjach wyjątkowych - w odniesieniu do wyodrębnionego merytorycznie postanowienia uchwały; w przeciwnym razie sąd może jedynie uchylić uchwałę w całości. Łączenie kilku spraw w jednej uchwale skutkuje tym, że właściciel głosuje jednakowo w odniesieniu do wszystkich zagadnień, a przecież może akceptować sprawozdanie zarządu, ale zarazem uznać, że jeden $z$ członków zarządu nie powinien otrzymać absolutorium, podczas gdy często sprawy te są ujmowane w jednej uchwale. Łączenie w jednej uchwale przedmiotowo różnych zagadnień nie powinno mieć miejsca, a taka sytuacja uzasadnia uchylenie uchwały w całości ${ }^{25}$, ale nie można wykluczyć, że zasadne może być w takiej sytuacji uchylenie uchwały w części,

${ }^{25}$ A. Sikorska-Lewandowska, Uchwały właścicieli lokali. Studium prawne, Warszawa 2017, s. 185. 
o ile takie żądanie sformułowano w pozwie. Będzie to zależało od ustaleń faktycznych poczynionych przez sąd w konkretnej sprawie.

\section{Charakter prawny uchwały w sprawie wybudowania ogrodzenia}

W uzasadnieniu glosowanego orzeczenia Sąd Najwyższy nie podjął rozważań na temat charakteru prawnego uchwały mającej za przedmiot zgodę na wybudowanie ogrodzenia na terenie nieruchomości. Wspólnota mieszkaniowa została $\mathrm{z}$ mocy prawa powołana do sprawowania zarządu nad nieruchomością wspólną, stanowiącą współwłasność właścicieli lokali. Decyzja o wybudowaniu ogrodzenia wokół całej działki należącej do wspólnoty musi zostać zakwalifikowana jako czynność przekraczająca zakres zwykłego zarządu, a więc wymagająca podjęcia uchwały przez właścicieli lokali, zgodnie $z$ art. 22 ust. 3 u.w.l., ze względu na znaczny koszt wybudowania takiego ogrodzenia oraz fakt, że jest to czynność zagospodarowania nieruchomością wspólną o istotnych skutkach dla wszystkich właścicieli tej nieruchomości.

Konsekwencją podjęcia takiej uchwały jest wyrażenie zgody na dokonanie przez zarząd czynności faktycznych i prawnych prowadzących do wykonania tej uchwały, a więc wybudowania tego ogrodzenia. Uchwała taka należy do kategorii tzw. uchwał upoważniających, a więc takiej, w której organ właścicielski wyraża zgodę, aby organ wykonawczy (zarząd) dokonał czynności o charakterze przekraczającym zakres zwykłego zarządu nieruchomością wspólną. Uchwała taka stanowi przesłankę ważności działań zarządu, gdyż w sprawach przekraczających zakres zwykłego zarządu konieczne jest jej podjęcie, działanie bez uchwały, jak się przyjmuje w doktrynie ${ }^{26}$, skutkuje zaś nieważnością czynności prawnej. Zaskarżenie przez właściciela lokalu takiej uchwały $z$ powołaniem się

${ }^{26}$ J. Kozińska, Status prawny zarządu wspólnoty mieszkaniowej-zagadnienia wybrane, „Rejent” 2003, nr 12, s. 129; P. Skibiński, Reprezentacja wspólnoty mieszkaniowej na gruncie ustawy o własności lokali, „Przegląd Sądowy" 2007, nr 5, s. 89. 
na zarzut naruszenia jego interesu musi prowadzić do ustalenia w postępowaniu dowodowym, czy interes powoda rzeczywiście na skutek powziętej uchwały został naruszony. Nie można jednakże zaakceptować stwierdzenia zawartego w uzasadnieniu głosowanego wyroku (s. 10), że do przyjęcia, iż istnieją przesłanki do uchylenia danej uchwały, musi istnieć co najmniej znaczna dysproporcja między potrzebą ochrony interesu właściciela a ochroną interesu wspólnoty mieszkaniowej. Przepis art. 25 u.w.1. nie formułuje kryterium „znacznej dysproporcji”, a przesłanka w postaci naruszenia interesu właściciela lokalu powinna być każdorazowo oceniana ad casum - sąd musi ustalić, czy w konkretnej sprawie na ochronę prawną zasługuje interes danego właściciela lokalu, czy interes wspólnoty mieszkaniowej.

\section{Podsumowanie}

W przypadku uchwały właścicieli lokali, której treść zawiera wyrażenie zgody na dokonanie przez zarząd określonej czynności prawnej, nie jest dopuszczalne uchylenie takiej uchwały w części, gdyż każdorazowo będzie to stanowiło niedopuszczalną ingerencję sądu w treść uchwały. Integralność treści uchwały wyklucza możliwość częściowego jej uchylenia. Sąd nie jest władny z własnej inicjatywy uchylić uchwały w części, takie orzeczenie może zapaść jedynie w sytuacji, gdy takie jest wyraźne żądanie pozwu. Uchylenie uchwały wspólnoty mieszkaniowej w części jest dopuszczalne tylko w zupełnie wyjątkowych okolicznościach, w przypadku gdy takie jest żądanie pozwu oraz jeśli w jednej uchwale skumulowano sprawy, które merytorycznie mogłyby, a nawet powinny stanowić dwie odrębne uchwały, albo tylko w przypadku, gdy zaskarżona część uchwały ma charakter autonomiczny i nie jest nierozerwalnie związana $z$ innymi elementami kwestionowanej czynności prawnej. 


\title{
STRESZCZENIE
}

\author{
Dopuszczalność ingerencji przez sąd \\ w treść uchwały wspólnoty mieszkaniowej - \\ glosa do wyroku Sądu Najwyższego z dnia 21 marca 2019 r., \\ sygn. II CSK 62/18 (krytyczna)
}

Przedmiotem glosy są rozważania na temat dopuszczalności uchylenia w części uchwały podjętej przez właścicieli lokali. Regulacja ustawy o własności lokali nie przyjmuje wprost takiego rozwiązania, ale zdaje się ono dopuszczalne na podstawie przepisów kodeksu cywilnego. Nie jest jednak możliwa ingerencja sądu w treść uchwały, jako oświadczenia woli ogółu właścicieli lokali, a więc wielostronnej czynności prawnej. Tylko wspólnota mieszkaniowa może zmodyfikować treść własnego oświadczenia woli, toteż co do zasady częściowe uchylenie uchwały należy uznać za niedopuszczalne.

Słowa kluczowe: uchwała wspólnoty mieszkaniowej; uchylenie uchwały; częściowe uchylenie uchwały

\section{SUMMARY}

Acceptability of court interference in the content of the resolution of the housing community gloss to the judgment of the Supreme Court of March 21, 2019, II CSK 62/18 (critical)

The subject of the gloss is the consideration of the admissibility of partially repealing the resolution adopted by the owners of the premises. The regulation of the Act on ownership of premises does not explicitly accept such a solution, but it seems to be allowed under the provisions of the Civil Code. However, it is not permissible for the court to interfere with the content of the resolution as a declaration of will by all owners of the premises, i.e. a multilateral legal action. Only a housing community may modify the content of its own declaration of will, therefore, as a rule, partial revocation of a resolution should be considered inadmissible. 
Key words: a resolution of a housing community; repealing a resolution; partial repeal of a resolution

\section{BIBLIOGRAFIA}

Bilewska K., Warzecha M., Dopuszczalność stosowania art. 58 § 3 k.c. do uchwał zgromadzeń spółek kapitałowych - polemika, „Przegląd Prawa Handlowego" 2010, nr 7.

Dziczek R., Własność lokali. Komentarz. Wzory pozwów i wniosków sądowych, Warszawa 2012.

Gutowski M., Dopuszczalność stosowania art. 58 § 3 k.c. do podlegających uchyleniu uchwał zgromadzenia wspólników lub walnego zgromadzenia spółek kapitałowych, „Przegląd Prawa Handlowego” 2009, nr 12.

Kidyba A., Prawo handlowe, wyd. 21, Warszawa 2019.

Kozińska J., Status prawny zarządu wspólnoty mieszkaniowej-zagadnienia wybrane, „Rejent” 2003, nr 12.

Naworski J.P., Uchylenie uchwały walnego zgromadzenia spółdzielni, „Przegląd Prawa Handlowego" 2003, nr 2.

W. Popiołek, w: Kodeks spółek handlowych. Komentarz, red. A. Strzępka, wyd. 7, Warszawa 2015.

Sikorska-Lewandowska A., Nieważność uchwał właścicieli lokali, „Państwo i Prawo" 2015, nr 2.

Sikorska-Lewandowska A., Uchwały właścicieli lokali. Studium prawne, Warszawa 2017.

Skibiński P., Reprezentacja wspólnoty mieszkaniowej na gruncie ustawy o własności lokali, „Przegląd Sądowy” 2007, nr 5.

Trzaskowski R., Skutki sprzeczności umów obligacyjnych z prawem, Warszawa 2013.

Zębala J., w: Prawo spółdzielcze i mieszkaniowe. Komentarz, red. K. Osajda, t. VI B, Warszawa 2018.

Zoll F., Kilka uwag na temat tzw. redukcji utrzymującej skuteczność, „Transformacje Prawa Prywatnego" 2000, nr 1-2. 